\title{
Absa Bank Limited v Keet 2015 JDR 0996 (SCA)
}

Should vindicatory claims be subject to prescription? A long-standing uncertainty resolved at last

\section{Introduction}

The question of whether claims for vindication of property should be subject to prescription is one which judges have offered a variety of views in recent years. Some of these have even been directly contradictory. For example, in Barnett and Others $v$ Minister of Land Affairs and Others (2007 6 SA 313 (SCA) (Barnett)) Brand JA, speaking for the full bench of the Supreme Court of Appeal (SCA), held that:

I am also prepared to accept that the vindicatory relief which the government seeks to enforce constitutes a 'debt' as contemplated by the Prescription Act. Though the Act does not define the term 'debt', it has been held that, for purposes of the Act, the term has a wide and general meaning and that it includes an obligation to do something or refrain from doing something. Thus understood, I can see no reason why it would not include a claim for the enforcement of an owner's rights to property (Barnett supra par 19).

However, more recently in Absa Bank Limited $v$ Keet (2015 JDR 0996 (SCA) $(A b s a))$ Zondi JA, writing on behalf of the full bench of the SCA, held ' $[\mathrm{i}] \mathrm{n}$ my view, there is merit in the argument that a vindicatory claim,

How to cite: Parker \& Zaal 'Absa Bank Limited v Keet 2015 JDR 0996 (SCA)' 
because it is a claim based on ownership of a thing, cannot be described as a debt as envisaged by the Prescription Act' (Absa par 20). He added that '[i]n the circumstances, the view that the vindicatory action is a "debt" as contemplated by the Prescription Act which prescribes after three years is, in my opinion, contrary to the scheme of the Act' (Absa par 25).

What then, led to such a complete turnaround? How did the SCA go from declaring the rei vindicatio to be a debt, in terms of the Prescription Act 68 of 1969 (the Act), which prescribes after three years, and then seven years later - to stating the exact opposite and holding that the rei vindicatio is in fact not a debt in terms of the Act and that it does not prescribe after three years? This contribution seeks to explore the answer to this question. The authors also trace what might be called a 'zig-zag course' which different judges have taken in recent years on whether vindication claims should be subject to prescription. The contribution pays particular attention to the Absa judgment as the most recent and important authority on this point. The analysis concludes by suggesting two reasons why the judgment of the SCA in $A b s a$, that vindication claims are not subject to prescription, should be adhered to in the future as the final and correct resolution of a long-standing judicial controversy.

\section{A Controversial Point of Law: Overview of the Earlier Decisions}

To properly appreciate the significance of the SCA judgment in Absa, it is necessary to have some understanding of earlier judicial views on whether the rei vindicatio is a debt that can prescribe. In the first part of the discussion, therefore, the modern South African decisions in which this point of law arose, are considered. In considering these decisions, it is appropriate to begin with Evins $v$ Shield Insurance Co Ltd (1979 3 SA 1136 (W) (Evins)) because it had a seminal influence on the jurisprudence which followed. In Evins there was no claim based on the rei vindicatio, but the Court had to consider the meaning of the word 'debt' in the Act. In doing so, the Court, per King J, held that debt 'must be given a wide and general meaning denoting not only a debt sounding in money which is due, but also, for example, a debt for the vindication of property' (Evins 1141 par F-G). This conclusion, in particular as it relates to vindication, was not commented on in a subsequent appeal judgment reported as Evins $v$ Shield Insurance Co Ltd 19802 SA 814 (A). It was also obiter because it was not relevant to the outcome of the case. However, the statement of the court a quo is significant for initiating more than three decades of confusion on whether the rei vindicatio is a debt which prescribes.

The first matter in which King J's wide definition of a debt exerted influence was Barnett. In this case, the government sued to vindicate land it alleged had been built on illegally. An issue that arose was whether or not its claim had prescribed because the buildings on the land had been erected at least six years prior to the issuing of the first summons. 
Although the special plea of prescription was unsuccessful on the basis that this was a continuing wrong which could not have prescribed, regardless of the time period, the Court, per Brand JA, held that

I am also prepared to accept that the vindicatory relief which the government seeks to enforce constitutes a "debt" as contemplated by the Prescription Act.

... Thus understood, I can see no reason why it would not include a claim for the enforcement of an owner's rights to property (Barnett supra par 19).

Brand JA approvingly referred to King J in Evins as having decided the same point correctly (Barnett par 19). Barnett thus confirmed the wide definition of a debt in Evins. However, once again nothing turned on the point because even if the rei vindicatio was a debt in terms of the Act that could prescribe after three years, prescription failed on the ground that there was a continuing wrong. Thus, the Court had not actually needed to apply its mind to the question of a correct understanding of a debt because it was going to make no difference to the outcome.

The question of whether vindicatory claims can prescribe surfaced again in Grobler v Oosthuizen (2009 5 SA 500 (SCA) (Grobler)). Here a claim based on cession was misinterpreted in the court a quo as resting essentially on the rei vindicatio. The claim was then challenged on the basis that it had prescribed. At an appeal hearing, the SCA decided that this claim was not based on the rei vindicatio (Grobler par 18). However, the Court disagreed with the court a quo, which had stated that the prescription period for the rei vindicatio was 30 years. In a confusing statement, even after concluding that the rei vindicatio had no role to play in this case, the Court still went on to state that the extinctive prescription period can only be three years (Grobler par 18).

In contrast to its unimportance in Evins, Barnett and Grobler, the question of whether vindicatory claims can prescribe at last became essential to reaching a decision in Leketi $v$ Tladi NO (2010 3 All SA 519 (SCA) (Leketi)). This matter involved an attempt to vindicate immovable property from an estate into which it had been fraudulently transferred. Relying on the above-mentioned obiter dictum in Barnett - that a 'debt' includes an owner's right to property and so prescribes in accordance with the Act - Mthiyane JA dismissed the claim. A disappointing aspect of the judgment is that despite the fact that only an obiter dictum was relied on, there was no discussion at all. The Court unquestioningly accepted that a claim for the return of property by an owner is a debt that prescribes. This was crucial to the outcome of the case because it meant that the owner's attempt to counter the effects of fraud failed.

The next matter in which the issue of a vindicatory right prescribing arose was Staegemann $v$ Langenhoven and Others (20115 SA 648 (WCC) (Staegemann)). This case involved a claim for the return of a motorvehicle from an innocent third party to whom it had been fraudulently sold. The claim was brought after more than three years and so the Court had to consider, as an essential question, whether the rei vindicatio had prescribed. Blignaut J's judgment is noteworthy as the first one in which 
this question was considered in some detail. He reasoned that the Act has two main parts: that concerning acquisitive prescription in chapters 1 and 2 , and that concerning extinctive prescription in chapter 3 . He opined that this division reflects the fundamental distinction in our law between actions in rem and actions in personam (Staegemann parr 20-21). The former apply to real rights in property, such as ownership and servitudes, which rights are subject to acquisitive prescription as referred to in the first two chapters of the Act. The latter deal with obligations and are the subject of chapter 3. It is only these rights which are extinguished after three years (Staegemann parr 14-21). This led him to conclude that ' $[\mathrm{t}]$ he rei vindicatio is clearly a claim to ownership in a thing. It cannot on any reasonable interpretation be described as a claim for payment of a debt' (Staegemann par 21).

Blignaut J briefly considered Road Accident Fund and Another $v$ Mdeyide (2011 2 SA 26 (CC) (Mdeyide)), where the Court considered the prescription of a claim against the Road Accident Fund, and not the rei vindicatio at all. Blignaut J noted that the Constitutional Court in Mdeyide (Staegemann par 24) relied briefly on the description of a debt from Barnett, which statement itself was obiter (Staegemann par 26), as was the statement relied on in Barnett from Evins (Staegemann par 27). Blignaut J was thus satisfied that he was not bound by any of these judgments in as far as they apply to the prescription of the rei vindicatio (Staegemann parr 23-28). He then concluded that actions based on the rei vindicatio are not subject to prescription (Staegemann par 28) and ordered that the motor vehicle be returned to the applicant (Staegemann par 39).

The correctness of Blignaut J's reasoning was briefly considered by the SCA in Bester NO and Others v Schmidt Bou Ontwikkelings CC (2013 1 SA 125 (SCA) (Bester)). This involved an application, inter alia, for rectification of title deeds where the whole, instead of only a portion, of a subdivided property had been registered in the name of a company, Innova - represented by its liquidators. The evidence was clear that the parties had intended to transfer only part of the property. The Court, per Brand JA, therefore confirmed that because their agreement had not been correctly implemented, despite the registration of ownership, Innova never became the owner of the property. The appellants, Innova's liquidators, argued that the respondent (the closed corporation which was the true owner of the property) was not able to apply for rectification of the transfer because its claim to do so had prescribed. The Court rejected this argument on two grounds. First, it concluded that rectification of a deed of transfer is, for relevant purposes, the same as the rectification of a contract. It noted that the SCA had previously held, in Boundary Financing Ltd $v$ Protea Property Holdings (Pty) Ltd (2009 3 SA 447 (SCA)) that the rectification of a contract does not equate to a debt in terms of the Act. This is because such rectification does not alter the legal rights and obligations of the parties. In the same way, rectification of a deed of transfer also does not alter existing rights. Therefore in Bester, Innova had never become the owner of the property. Furthermore, there was no claim for vindication, merely rectification and because there was 
no debt, the claim did not prescribe in terms of the Act (Bester parr 1012). Second, the Court held that even if the word 'debt' is to be given a wider meaning, the situation in a case involving rectification still does not amount to a debt (Bester parr 13-14).

Since the Court in Bester concluded that the respondent's claim was based on rectification rather than vindication, it did not need to decide whether the latter amounts to a debt prescribing after three years. Despite this however, Brand JA went on to refer to his own earlier favouring of prescription of vindicatory claims in Barnett, and that Staegemann had questioned the correctness of this. He then conceded that:

I must admit that I find the reasoning in Staegemann attractive and, at least on the face of it, quite convincing. I therefore have no doubt that the case will come where this court will have to reconsider the correctness of the decisions in Barnett, Grobler and Leketi that the rei vindicatio is extinguished by prescription after three years. But this is not that case, simply because the liquidators' prescription defence has already been held to founder on other grounds (Bester supra par 15).

By 2013, therefore, the question of whether vindicatory claims can prescribe - despite numerous judicial pronouncements - had not been firmly settled. The case in which the point was finally to be decided definitively, some two years later, was Absa. The reasoning in the judgment $a$ quo and in the appeal to the SCA in the Absa case will now be considered.

\section{The Facts and Judgment of the Court a Quo in Absa V Keet}

The facts in Absa were not unusual. Eastvaal Motors Ltd had sold a vehicle to Keet in terms of an instalment sale. Eastvaal Motors' right, title and interest in and to the agreement was then ceded to Absa Bank. Keet took delivery of the vehicle. In terms of the agreement, ownership would not pass to Keet until the outstanding money owed in terms of the sale was paid in full. The final instalment was due to be paid in November 2007. The agreement allowed Absa Bank to take possession of the vehicle if Keet failed to comply with any terms of the sale. Absa Bank was also entitled to demand payment of any outstanding instalments. More than four years after the agreement ought to have come to an end, Absa Bank instituted an action in the High Court for repossession of the vehicle, alleging that Keet had defaulted on his payments (Absa Bank Ltd $v$ Keet 2013 JDR 1701 (GNP); in the part that follows immediately below, all paragraph references are to this 2013 judgment). In response, Keet raised a special plea of prescription. He contended that more than three years had passed since the agreement would have come to an end and Absa Bank, therefore, was not entitled to cancel it or to claim the recovery of the vehicle (parr 2-5). In reply Absa Bank, relying on Staegemann (supra), argued that as title is only acquired through 
acquisitive prescription after 30 years, the right of an owner to vindicate his property can only prescribe after 30 years (par 5).

The sole question to be decided arose from the special plea. Thus, whether vindicatory claims prescribe after three years was the essential issue and only issue. In its analysis, the Court focused on the application of section 10 of the Act to the rei vindicatio. In so doing, Fabricius J found himself confronted by the differing judicial opinions noted above. After considering them, he decided to follow Evins, Barnett, Grobler and Leketi. This was expressly in preference to following the two more recent judgments in Staegemann and Bester. As should be remembered, in the latter two cases the courts had favoured the view that vindicatory claims should not prescribe. In rejecting them, Fabricius $\mathrm{J}$ decided that Staegemann was incorrect in concluding that Barnett was obiter on the point. He also relied on the fact that in Barnett, four other judges had concurred with Brand JA's original view (parr 6-8). Although he quoted the later view of Brand JA in Bester, that 'I must admit that I find the reasoning in Staegeman ( $\mathrm{sic}$ ) attractive and, at least on the face of it, quite convincing', Fabricius J nevertheless found that Staegemann was not in line with other authorities and rejected its obiter reasoning on vindicatio (par 10). The special plea in Absa was therefore successful in the court a quo. Fabricius J concluded that delivery of the vehicle created a debt, which had prescribed after three years.

\section{The Appeal Decision}

Absa Bank appealed to the SCA. However, the parties reached a settlement prior to the hearing and the SCA had to decide whether or not it should still consider the matter. It concluded that it should do so because although courts are generally reluctant to hear moot points, the case raised a matter of public importance and there was uncertainty in the law resulting from the mixed views offered by courts in previous decisions (Absa supra parr 7-8). The Court, after noting the facts, reviewed the dicta concerning vindication and prescription in Evins, Barnett, Grobler, Leketi, Bester and Staegemann (Absa parr 12-19). In particular, the Court approved of the comments in Staegemann. It agreed with the conclusion in the latter that the solution to the previous uncertainty concerning prescription is to be found in the distinction between real rights and personal rights.

Zondi JA decided that the obligation imposed on a debtor does not create a real right, but a personal right. In contrast, 'a vindicatory claim, because it is a claim based on ownership of a thing, cannot be described as a debt as envisaged by the Prescription Act' (Absa par 20). In support of this, he noted that the distinction between real and personal rights had been consistently confirmed by our courts. As an example of this he cited paragraph 31 in National Stadium South Africa (Pty) Ltd $v$ Firstrand Bank Ltd (20112 SA 157 (SCA); Absa par 21). He agreed with Staegemann that the Act also reflects this distinction. Acquisitive prescription of real rights is the subject of chapters 1 and 2 of the Act, and extinctive prescription 
of obligations is dealt with separately in chapter 3 . He quoted from a memorandum submitted by Professor JC de Wet (who drafted the Act) to parliament. This emphasised that extinctive and acquisitive prescription are two separate legal concepts. In relation to debts, Zondi JA noted, with approval, a remark by De Wet in the memorandum that '[i]n the case of extinctive prescription one is more specifically concerned with the relationship between creditor and debtor and prescription serves in the first instance to protect the debtor against claims that perhaps never came into existence or had already been extinguished' (Absa par 24).

The Court opined that viewing the rei vindicatio as a debt which prescribes after three years is 'contrary to the scheme of the Act' (Absa par 25). This would in fact 'undermine' the distinction in the Act between extinctive and acquisitive prescription - the former dealing with the debtor-creditor relationship and the latter dealing with real rights (Absa par 25). With extinctive prescription, the creditor loses his right to bring an action against the debtor - the personal right, but he does not lose his right in a thing. The Court added that to regard the vindicatory action as a debt, would mean that debtors effectively acquire ownership of property after three years instead of 30. Owners/creditors would not be permitted to enforce ownership rights after a mere three years, even though in terms of acquisitive prescription, they should have at least 30 years to do so. He concluded that this is 'absurd' and 'not a sensible interpretation' (Absa par 25).

Zondi JA did concede that the SCA had, in three previous judgments, expressed a view contrary to the approach favoured by him. However, he noted that those decisions were not dependent on the views expressed in them concerning the rei vindicatio. He added that, even if the views expressed are regarded as being part of the ratio, they were wrong in law and that it was appropriate for the SCA to now depart from its earlier decisions. He submitted that to do so is not problematic because Barnett, as the main contrary previous decision, is recent and so would not yet have impacted significantly on commercial practice. Brand JA, as author of that contrary conclusion, had himself subsequently indicated in Bester that his view needed reconsideration (Bester supra par 15). And finally, the Court concluded that perpetuating the incorrect view would promote absurdity (Absa par 26). Zondi JA thus upheld the appeal and dismissed the special plea. He found that the court a quo was incorrect in finding that a claim for delivery is a debt that prescribes after three years in terms of the Act (Absa par 27).

\section{Comments and Concluding Remarks}

As has been shown, there has been considerable judicial variance on whether vindicatory claims should prescribe after three years. Judicial approaches to this question have gone through many twists and turns before what appears to be a final resolution at last by the SCA in Absa. What was merely a peripheral and barely considered comment in passing in Evins was accepted by the SCA in Barnett. It was then re- 
iterated by the SCA in Grobler, applied by the SCA in Leketi and not applied in Staegemann. It was subsequently questioned in Bester (Brand JA doubting his own previous opinion in Barnett), applied once again by the court a quo in Absa and then finally rejected by the SCA in the Absa appeal judgment.

The foundational cause of judicial confusion was the absence of any definition of what constitutes a debt for purposes of the Prescription Act. The beginning of the problem, resulting from this legislative lacuna, can be seen in the unfortunate holding in Evins that the word 'debt' in the Act 'must be given a wide and general meaning denoting not only a debt sounding in money which is due, but also, for example, a debt for the vindication of property' (Evins supra $1141 \mathrm{~F}-\mathrm{G}$ ). Although this statement started all the uncertainty which followed, it is not clear why the Court in Evins thought that a claim for vindication of property would amount to a debt. This had no significance in this case and was not explained. Clearly, this view was incorrect because it conflated an action in rem with an action in personam.

Ironically, many of the dicta which sowed further confusion in the wake of Evins were equally unnecessary. The decision as to whether or not the rei vindicatio prescribes after three years was only relevant in Leketi and Staegemann. And in Leketi it was simply assumed, without discussion, that any obligation by an estate to return fraudulently acquired property to its rightful owner was a debt. There was no exploration of how this supposed debt had arisen and, in particular, no interrogation of the implications of fraud. There was no consideration of the fact that the claim by the rightful owner was based on ownership. The claim was thus a ius in rem and not a claim based on any obligationcreating event. It was certainly not a ius in personam, and thus arguably not a debt. Most of the discussion in the case was around when the time periods necessary for the prescription of a debt should start and end. Thus, Leketi provided little meaningful assistance as a precedent for subjecting vindication to prescription because the Court did not apply its mind to the legal status of a claim based on a real right.

Although the precedent set by the SCA in Leketi was a weak one, the ultimate rejection of it by the SCA in Absa was far from predictable. If Brand JA in Bester had not decided to add an obiter dictum approving the approach of the High Court in Staegemann and questioning his own previous approach, it is possible that the view might have become entrenched into law that the rei vindicatio is a debt for purposes of the Act. Fortunately, however, Brand JA's reconsideration opened the door to a possible future new approach by the SCA. In view of this, if the trial in Absa had been heard before another judge rather than Fabricius J, it is conceivable that the issue would not have come back to the SCA. But, in yet another unpredictable turn of events, the Absa court a quo chose to discount the more recent signals from the SCA which were against the idea that vindicatory claims should prescribe within three years. Instead, it favoured the earlier decisions where the issue was either irrelevant or 
had not yet been carefully interrogated. The approach of the court a quo in Absa was surprising because it canvassed the issue in some detail. It had access to the Staegemann judgment, which explained very clearly the scheme of the Act and the distinction between claims based on real and personal rights. The statement in Bester, which approved of Staegemann, was also available to it. Yet it still persisted in disregarding the implications of the distinction.

The overruling of the decision of the Absa court a quo by the SCA is to be welcomed. Since the appeal court holding that vindicatory claims do not prescribe after three years was essential for purposes of its conclusion and thus is clearly not obiter, it may safely be accepted that the uncertainty concerning this point of law has at last been resolved. It is the submission of the authors that the SCA judgment is clearly correct for two main reasons. First, it accords with the nuanced approach in our law to real and personal rights. It recognises the primary distinction between these, and their corresponding actions. Real rights arise out of a relationship with a thing and personal rights out of an obligationcreating event, such as a contract or delict. It is trite to say that real rights are enforceable against the world at large and personal rights only as against the other person. The creation of a personal right with its correlative obligation results in a creditor-debtor relationship, but no such relationship flows from the creation of a real right. Because of the fundamental difference in nature between real and personal rights, they require different remedies for their enforcement. In relation to personal rights, for example, delictual remedies are available to enforce rights arising out of delicts, and contractual remedies are available to enforce rights that arise out of contractual relationships. The protection of a real right is quite different - the main remedy is, of course, the rei vindicatio which is available to an owner for the return of the possession of his or her property, but there are other remedies such as the actio negatoria available to protect limited real rights. The Absa appeal decision, in recognising that vindicatory claims need to be treated differently from debts relating to personal rights, supports the durable and sui generis nature of the rei vindicatio.

A related consideration is that the decision also fits with the basic design of the Prescription Act. As has been noted this is divided into the two main parts. It will be remembered that chapter 3 of the Act deals with extinction of debts and thus indicates the circumstances under which a creditor may no longer enforce a personal right due to effluxion of time. This chapter makes specific reference to a 'debt' (in ss 10-16). It also makes reference to a debtor (in ss 10-16) and creditor (in ss 12,13 $\&$ 15). Therefore, it ought to be interpreted as envisaging a debtorcreditor relationship which would need to arise from some obligationcreating event such as a delict or contract. Chapter 1 of the Act, however, deals with real rights and specifically with the acquisition of ownership. Again, in recognising that vindication of ownership claims should be dealt with very differently from personal right claims, the Absa appeal decision accords with the structure of the Act. Furthermore, in 
delineating that a debt for purposes of the Act does not include vindicatory claims, it helps address the problems resulting from the failure to define a debt in the Act.

Second, and most importantly, the Absa appeal judgment is to be commended for removing the absurdity resulting from the previous decisions holding that the rei vindicatio prescribes. As was pointed out by Zondi JA (Absa supra par 25), a conclusion that the remedy available to an owner to have his or her property returned prescribes after three years has a peculiar consequence. If someone else has been in adverse possession of the property for more than three years, the owner no longer has a remedy and can do nothing to vindicate the property. The possessor or successors in title will only acquire ownership after 30 years. Quite clearly, this long delay in anyone having full rights to property makes no sense at all. The intended scheme in the Act could never have been that owners are prevented from asserting ownership rights and recovering property after three years, while adverse users can continue in mere possession until such time as 30 years has expired. Once this is appreciated, it becomes obvious that it is inappropriate to regard a claim for the recovery of property as a debt which prescribes after three years. Why, it might be asked, was this not recognised in most of the reported cases in which the issue was referred to? It would seem that in these matters the courts focused more on formulating a position than on exploring its consequences.

Finally, the Absa appeal decision appropriately recognises that the division between real and personal rights informs the distinction drawn between acquisitive and extinctive prescription in the Act. It also avoids the absurdity resulting from conflating personal and real right claims in such a way that an owner's right to vindicate property becomes prescribed after a mere three years. After what might be termed a somewhat turbulent recent history of the point in the courts, the holding of the SCA in Absa, that vindicatory claims do not prescribe after three years, has brought about a significant and hopefully permanent improvement in the law - in this regard it should perhaps be noted that the Absa decision has been met with approval in both the SCA and the Constitutional Court (see Fedgroup Participation Bond Managers (Pty) Ltd $v$ Trustee, Capital Property Trust 2015 (5) SA 290 (SCA) n 23; and Makate $v$ Vodacom Ltd 2016 (4) SA 121 (CC) parr 189-190).

J PARKER

University of KwaZulu-Natal

FN ZAAL

University of KwaZulu-Natal 